\title{
The Tax Implications of Global Warming: Preparing for a Change of Climate
}

\author{
Edoardo Traversa*
}

International taxation is experiencing major developments in different fields: tax transparency and exchange of information; tax avoidance and the base erosion and profit shifting (BEPS) Project; and now proposals on digital taxation that are likely to affect the founding principles of the international allocation of corporate tax bases.

Yet those evolutions, although remarkable in their magnitude when compared to what occurred in the last decades, appear to be minimal and even shortsighted if put into a broader context.

There is indeed a stunning absence of debate in international tax circles about what appears to be, beyond any reasonable doubt, the greatest danger that humanity has faced in centuries: climate change.

This author will not attempt to summarize here the countless items of evidence elucidated by the scientific community regarding the deterioration of the living conditions of plants, animals, and human beings on the six continents. ${ }^{1}$ Rising record temperatures, loss of biodiversity, destruction of natural resources, and the increase of natural and human-caused disasters are just few examples of how global warming affects our everyday lives, and the younger generations should prepare for much more radical transformations. Even the most optimistic predictions forewarn us that parts of the world will soon become uninhabitable (whether under water or extremely hot) with global consequences regarding migration, food chains, health and stability, and peace. It is needless to state that those changes will inevitably affect trade and economic activities and, of course, taxation systems. However, there should also be awareness that the way trade and economic activities are currently conducted are one of the primary causes of global warming. The ever increasing levels of emission of greenhouse gases are indeed the direct consequence of the massive use of fossil energy sources as well as mass production and commercialization processes that are typical of our globalized economies.

Tax rules have also played an important role in easing this process. For decades, governments, businesses, and tax experts have actively devised, advocated, and eventually adopted rules that would facilitate cross-border trade, whether motivated by self-interest or by a genuine desire to increase global prosperity and peace. This was the case in both the area of direct taxation with the adoption of approximately 4000 bilateral tax treaties and in indirect taxation with the gradual decrease if not the abolition of custom duties and replacement by trade friendly systems of taxation like the Value Added Tax (VAT)/Goods and Services Tax (GST). Taxation has been a tool that has been exploited to promote political objectives of free trade and globalization and believed to be in the best interest of humanity.

Yet the time has come for a rational assessment. It is not about undoing what has been patiently constructed during the last decade for purely ideological motives, but it is about lucidly analysing the side effects of tax policies that initially established objectives that should now be weighted against other imperatives. In particular, there should be awareness that our current way of understanding neutrality and nondiscrimination between economic activities (from a cross-border perspective but also at the domestic level) is fully disconnected from the environmental consequences it entails.

The European Commission has proposed the Green Deal as its flagship program, a series of measures aiming at curbing carbon omissions in Europe and achieving carbon neutrality by $2050 .^{2}$ At the moment, it is unclear what type of measures the Commission has in mind, whether it is a revamping of the emission trading scheme, a revision of the 2003/96/EC Energy tax directive, or an overhaul of the

\section{Notes}

Professor of tax law, UCLouvain. Email: edoardo.traversa@uclouvain.be.

See the IPPC Reports, https://www.ipcc.ch/reports/ (accessed 17 Feb. 2020), in particular the Special Report on the impacts of global warming of $1.5^{\circ} \mathrm{C}$ above pre-industrial levels and related global greenhouse gas emission pathways (IPCC 2018).

2 European Commission, A European Green Deal - Striving to Be the First Climate-Neutral Continent, https://ec.europa.eu/info/strategy/priorities-2019-2024/european-green-deal_ en (accessed 17 Feb. 2020). 
customs and anti-dumping legislation. And, even more important, it is hard to predict whether the Commission will get enough political support for any of those alternatives. Nevertheless, it is extremely important that environmental concerns have been put at the top of the European agenda. This constitutes an important step toward exerting pressure on reluctant partners (whether EU Member States or not) and to bring the topic to an international forum such as the OECD or the UN.

However, the fight against global warming cannot be limited to global circles. Curbing climate change is indeed a challenge that will require policy efforts at every level of government, and this will not only necessitate political will but also interdisciplinary and crosssectoral expertise. Preparing our tax systems for this new challenge will not be easy, especially considering the already high level of taxation in developed countries and particularly in the European Union. Beyond the adoption of carbon taxes ${ }^{3}$ and border tax adjustments at the EU level, ${ }^{4}$ there must be preparation for reviewing entire parts of the tax systems, for analysing the effects of each tax measure on carbon emissions, and assessing the feasibility of reforms that are currently envisaged by individuals who are concerned about climate change whether they are economists, engineers, philosophers, or creative laymen.

In the area of income taxation, this will mean addressing rules on deduction, whether personal or business expenses, such as car-related costs, rules on amortization, and special deductions for investments; it could also impact the tax treatment of income from immovable property in order to take into consideration the energy performance of buildings. It could also imply increasing the level of the minimum taxable income in order to compensate for the effects of a probable increase in the cost of energy (whether through taxes or market mechanisms).

At the level of indirect taxation, excise duties will have to be thoroughly revised in order to make a distinction between energy sources and the various types of energy use. VAT rules also will need to be reassessed, at least regarding reduced rates and exemptions. Rules on deduction and revision for immovable property could also be reconsidered, and a sustainability component could even be integrated into the definition of the taxable base. ${ }^{5}$ Estate and registration duties as well as the real estate taxes should also undergo a thorough compatibility check with environmental objectives.

These are just a few examples of the task that lies ahead for tax specialists. Of course, some of these measures could encounter political or administrative hurdles and not be adopted. However, that should not be a reason for the tax community to ignore the impact of this source of major concern for the rest of the world. Taxation has a significant role to play in the planning of a sustainable climate transition, and tax specialists should take their part.

\section{Notes}

C. Gollier, Le Climat après la fin du mois (PUF 2019), English translation forthcoming.

4 A. Pirlot, Environmental Border Tax Adjustments and International Trade Law. Fostering Environmental Protection (Edward Elgar 2017).

B. Timmermans \& W. Achten, From Value-Added Tax to a Damage and Value-Added Tax Partially Based on Life Cycle Assessment: Principles and Feasibility, 23(11) Int'l J. Life Cycle Assessment 2217-2247 (Nov. 2018). 